\title{
Assessment of aquifer vulnerability for pollution for middle delta in Egypt using Geographic Information System and DRASTIC technique
}

\author{
Aziza A. Khalifa ${ }^{1}$, Mohamed M. Elshemy ${ }^{1}$, Alaa A. Masoud ${ }^{2}$, I. M. H. Rashwan ${ }^{1}$ \\ 1 Irrigation and Hydraulics Dept., Faculty of Engineering, Tanta University, Egypt \\ 2 Professor of Geology, Geology Department, Faculty of Science, Tanta University, Egypt
}

\begin{abstract}
Egypt is one of the countries suffering from water poverty, so researches must be increased about groundwater as a clean source of water. Aquifer vulnerability has assessed using the DRASTIC method, based on a Geographic Information System (GIS) to evaluate the relative importance of the model parameters for aquifer vulnerability in middle Delta Gharbiya Governorate (Egypt). An additional objective is to demonstrate the combined use of the DRASTIC with GIS system as an effective method for groundwater pollution vulnerability. The DRASTIC model uses seven hydrological factors (Depth to water, net Recharge, Aquifer media, Soil media, Topography, Impact of the vadose zone, and hydraulic Conductivity) to characterize the hydrogeological setting and evaluate aquifer vulnerability. A DRASTIC vulnerability map, verified by nitrate in groundwater data, shows that the defined areas are compatible with land-use data. It is concluded that these values were reclassified into four classes, low (132-146) "24\%", medium (146-159) "30\%", high (159-172) "35\%", and very high "11\%", of the study area, respectively.
\end{abstract}

Keywords: $\quad$ DRASTIC; $\quad$ Arc-GIS; vulnerability; Groundwater; Contamination

\section{INTRODUCTION}

ROUNDWATER has been considered as an important source of water supply due to its relatively low susceptibility to pollution in comparison to surface water, and its large storage capacity. However, there are significant sources of groundwater pollution from land use activities, particularly agricultural practices. The intrusion of these pollutants to groundwater alters the water quality and reduces its value to the consumer (Melloul and Collin, 1998). Prevention of contamination is therefore critical for effective groundwater management. Spatial variability and data constraints preclude monitoring all groundwater and make remediation activities expensive and often impractical. Vulnerability assessment has recognized its ability to delineate areas that are more likely than others to become contaminated a result of anthropogenic activities at the earth's surface. Several threats to groundwater resources reduced by identifying and controlling distinct sources of pollution.

There are several threats to groundwater in the Nile Delta, such as contamination with wastewater and pesticides, and saltwater intrusion (Kashef 1983; Ebraheem et al. 1997; Gemail et al. 2011; Attwa et al. 2014; Mabrouk et al. 2015). Currently, in the Nile Delta region, there is an everincreasing demand for the use of fertilizers and pesticides in agricultural activities. In turn, there has been an expansion of settlements and industries but without proper installation of sewer and drainage systems and with poor practices of waste disposal management. In agricultural areas such as the Nile Delta, wastewater in open drains can penetrate into the unsaturated zone above the aquifer and reach the aquifer down to a depth of 15-20 m below the surface. Prevention of pollution of shallow aquifers considered a valuable goal in water resource management (El-Alfy 2012). In such condition, assessment of aquifer vulnerability can play an essential role in the protection and management of groundwater resources.

The assessment of groundwater vulnerability to pollution has been the subject to intensive research during the past years and a variety of methods has developed. Many approaches developed to evaluate aquifer vulnerability. For this objective, the GIS and remote sensing tools combined with various methods: standard DRASTIC, GOD, SINTACS and SI method and used to evaluate aquifer vulnerability to pollution. The DRASTIC method is a familiar method developed in the US Environmental Protection Agency (USEPA) by (Aller et al. 1987). This method was applied in several regions by different researchers: Merchant (1994); Melloul and Collin 1998; Kim and Hamm 1999; Cameron and Peloso 2001; Al-Zabet 2002; Al-Adamat et al. 2003; Baalousha 2006; Jamrah et al. 2007; Sener et al. 2009; Oroji and Karimi 2017; Barzergar et al. 2017; Mfonka et al.2018; Shakoor et al. 2018; Machdar et al. 2018; Joshi and Gupta 2018; Ahirwar,and Shukla 2018; Sadiki,et al 2018; Lad et al. 2018). Some of the researchers modified the DRASTIC method and added different parameters (Secunda et al. 1998; Lee 2003; Mendoza and Barmen 2006; Wang et al. 2007) such as land use index, lineaments, aquifer thickness, and impact of contaminant. Thirumalaivasan et al. (2003) developed a software package AHP-DRASTIC to derive ratings and weights of modified DRASTIC model parameters.

\section{STUDY AREA: GHARBIYA GOVERNORATE}

Gharbiya Governorate is in the middle delta in Egypt and is located between the two main branches of the Nile Rosetta to the west and Damietta to the east. The area is $1942 \mathrm{~km}^{2}$ falls between latitudes $30^{\circ} 35^{\prime}, 31^{\circ} 10^{\prime} \mathrm{N}$ and longitude $30^{\circ}$ $45^{\prime}, 31^{\circ} 15^{\prime} \mathrm{E}$ (Figure 1).

The land use varies between cultivated $\left(1658 \mathrm{~km}^{2}\right)$, residential $\left(214 \mathrm{~km}^{2}\right)$, and barren lands $\left(70 \mathrm{~km}^{2}\right)$. The Governorate consists of 8 districts, 317 villages, and 1249 small hamlets. The governorate is marked third (2608 persons $/ \mathrm{km}^{2}$ ) of the highly populated governorates in Egypt. 
The population has reached $5,066,000$ in 2018, which doubled since 1976.

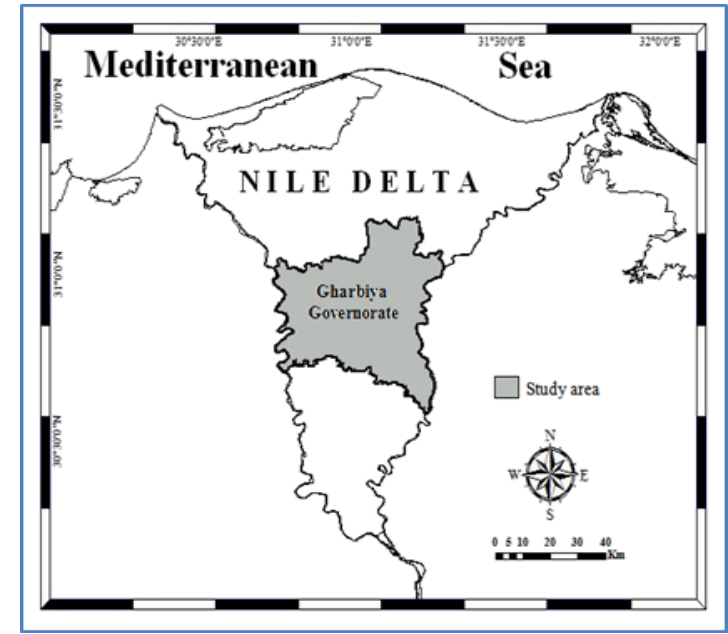

Figure 1. Study area

\section{A. Geology and Hydrogeology}

The geology and hydrogeology of the Nile Delta region has been studied by several authors, e.g., (Attia 1975), (Gheith 1976), (Zaghloul et al.1977, 1979), (El-Fawal 1979), (Said 1981), (Sestini 1989), (El-Fayoumi et al. 1991), (Bahr 1992), (Sherif 1999), (Sherif and Singh 2002), (Sherif et al. 2012), and (Abd-Elhamid et al. 2016). The Nile Delta region has a thick stratigraphic sequence of Neogene to Quaternary sediments (Zaghloul et al. 1977), (Said 1981), (Sherif 1999). This includes Miocene sediments (Sidi Salim Fm., Qawasim Fm., and Rosetta Fm.), Pleistocene sediments (Abou Madi Fm., Kafer El-Sheikh Fm., El-Wastani Fm., and Mit Ghamer Fm.), and Holocene sediments (Bilqas Fm.).

The most important geological units for groundwater are the Mit Ghamr Fm. and El Wastani Fm., as they form the main aquifer and the Bilqas Fm. considered as an aquitard. The Holocene Bilqas Fm. refers to the coastal lagoonal environment made up of silts and sandy mud that form the agricultural soil. The lower part of the Bilqas Fm. is silty and fine sand a few meters in thickness, with higher hydraulic conductivity than that of the upper clay layer (Sherif 1999). In the southern part of the study area, this formation is a few meters thick (Troger et al. 1993). Well, logs show that this clay cap underfed by a thick succession of unconsolidated sand and gravel of the Mit Ghamr Fm. and El Wastani Fm. The Bilqas Fm. in the Nile Delta acts as a protection zone of the subsurface sandy aquifer (Khaled et al. 2017). Thus, in the present study, the heterogeneity in this protection zone considered as the targets for the assessment and mapping processes.

The quaternary sediments in Gharbia governorate divided into two hydrographic units, a layer the semi-activated Holocene, and the main reservoir belonging to the Pleistocene area.

As Sherif (1999) mentioned, the average value of the hydraulic conductivity of the clay protection zone in the Nile Delta is $2.9 \times 10^{-8} \mathrm{~m} / \mathrm{s}$. The hydraulic conductivity of the Nile
Delta aquifer varies between $6.8 \times 10^{-4}$ and $8.2 \times 10^{-4} \mathrm{~m} / \mathrm{s}$ in the south-western and northern parts of the Nile Delta, whereas it attains its maximum values $\left(1.21 \times \times^{10-3}-2.12 \times 10^{-3}\right.$ $\mathrm{m} / \mathrm{s}$ ) in the central and southeastern parts (Dahab 1993). In the study area, several pumping tests have performed in the past, which revealed the average hydraulic conductivity to be $1.2 \times 10^{-3} \mathrm{~m} / \mathrm{s}$, the average transmissivity to be $10.26 \mathrm{~m} 2 / \mathrm{s}$, and the average storage coefficient to be $1.5 \times 10^{-4}$.

\section{Methodology}

DRASTIC has been the most common aquifer vulnerability assessment method; however, it is not intended to predict the occurrence of groundwater contamination (USEPA 1985). Geographical information system "ArcGIS" provides a powerful suite of statistical models and tools for spatial data exploration and optimal surface generation. It allows creating a statistically valid prediction surface, along with prediction uncertainties, from a limited number of data measurements. From determining an environmental safety threshold has exceeded in locating mineral deposits. ArcGIS Geostatistical Analyst helps to model spatial data in a reliable and intelligent way. ArcGIS Geostatistical Analyst enables to take advantage of these tools and techniques in an interactive graphical user interface (GUI) and as web services.

\section{A. Description of the DRASTIC technique}

A DRASTIC technique was obtained from ratings and weights associated with seven parameters: these are (D) depth to groundwater, $(\mathrm{R})$ net recharge, $(\mathrm{A})$ aquifer media, (S) soil media, (T) topography, (I) influence of the vadose zone, and (C) hydraulic conductivity. Each parameter is subdivided into ranges and is assigned different ratings in a scale of one (least contamination potential) to 10 (highest contamination potential) based on functional curves (Table 1).

This rating is scaled by DRASTIC weighting factor ranging between one (least significant) and five (most significant), (Sener et al. 2009). In this study, nitrate weight used for alluvium areas and DRASTIC weight used for the other areas of the study area. The linear additive combination of the above parameters with the ratings and weights used to calculate the DRASTIC Vulnerability Index $(D V I)$ as given below (Aller et al. 1987):

$$
\begin{aligned}
D V I=\mathrm{D}_{\mathrm{R}} \mathrm{D}_{\mathrm{W}}+ & \mathrm{R}_{\mathrm{R}} \mathrm{R}_{\mathrm{W}}+\mathrm{A}_{\mathrm{R}} \mathrm{A}_{\mathrm{W}}+S_{R} S_{W} \\
& +\mathrm{T}_{\mathrm{R}} \mathrm{T}_{\mathrm{W}}+\mathrm{I}_{\mathrm{R}} \mathrm{I}_{\mathrm{W}}+\mathrm{C}_{\mathrm{R}} \mathrm{C}_{\mathrm{W}}
\end{aligned}
$$

where $D_{R}$ is rating for the depth to water table, $D_{W}$ is weight assigned to the depth to water table, $R_{R}$ is rating for aquifer recharge, $R_{W}$ is weight for aquifer recharge, $A_{R}$ is rating assigned to aquifer media, $\mathrm{A}_{\mathrm{W}}$ is weight assigned to aquifer media, $S_{R}$ is rating for the soil media, $S_{W}$ is weight for the soil media, $T_{R}$ is rating for topography (slope), $T_{W}$ is weight assigned to topography, $I_{R}$ is rating assigned to impact of the vadose zone, $\mathrm{I}_{\mathrm{W}}$ is weight assigned to impact of the vadose zone, $C_{R}$ is rating for rates of hydraulic conductivity; and $\mathrm{C}_{\mathrm{W}}$ is weight for rates of hydraulic conductivity.

When determining the values of the DRASTIC index, probably it identifies areas that are susceptible to 
contamination of groundwater to compare to each other. The DVI value classes are low, medium and high were determined using the quantile classification method. The high value for DRASTIC index refers to high groundwater pollution vulnerability (Lee 2003). In this study, all parameter maps digitized in the geographic information system environment and vulnerability classification of the study area are produced by geographic information system techniques. Seven data layers are digitized and converted to raster layers using ArcGIS. Then, the DVI computed and the vulnerability map of the study area was prepared taken into consideration hydrogeological field observations and investigations. Weighting factors of the seven parameters were determined based on the site characteristics, which presented in (Table 1). Validation of the DRASTIC vulnerability map carried out using groundwater quality data such as Nitrates "NO3" since high mainly arises from surface sources like agricultural activities and urban pollution.

\section{B. Preparation of the aquifer (DRASTIC) vulnerability map}

The seven maps using vulnerability assessment of the study area with the DRASTIC method were prepared using hydrogeological data based on GIS-Arc View. Each parameter of the DRASTIC method has explained as follows:

Depth to the water table (D)

Depth to groundwater is important because it determines the depth of the substance through which the pollutant passes before reaching the saturated aquifer. (Al-Zabet 2002). In this study, groundwater level measurements have made in 476 piezometers from the previous investigation studies (Masoud et al. 2017), and 34 soil sediments from technical reports of soil investigation from Education Buildings Authority carried out for this study area.

The Groundwater depth raster map of the study area was prepared using the inverse distance weight (IDW) interpolation method of ArcGIS Spatial Analyst (Figure 2). The rating for depth to water table varies from 10 (for $0-1.5$ $\mathrm{m})$, to 1 (for $>30 \mathrm{~m}$ ) (Table 1). According to raster map for depth to groundwater, groundwater is shallow in the middle of Delta, and has high ranges between $9.1 \mathrm{~m}$ and $12.2 \mathrm{~m}$ in the southeastern and southwestern parts of the study area, whereas the rating weight between $1.5 \mathrm{~m}$ and $4.6 \mathrm{~m}$ in the northern part.

\section{Net recharge $(R)$}

Groundwater pollutants can easily pass through groundwater depending on the amount of filtration water. Therefore, the net recharge is a very important factor for assessing the vulnerability of the aquifer. The Nile Delta aquifer is recharged by leakage infiltration from a network of irrigation canals, excess irrigation water, and precipitation that percolates through the upper clay layer, (Armanuos et al. 2017).

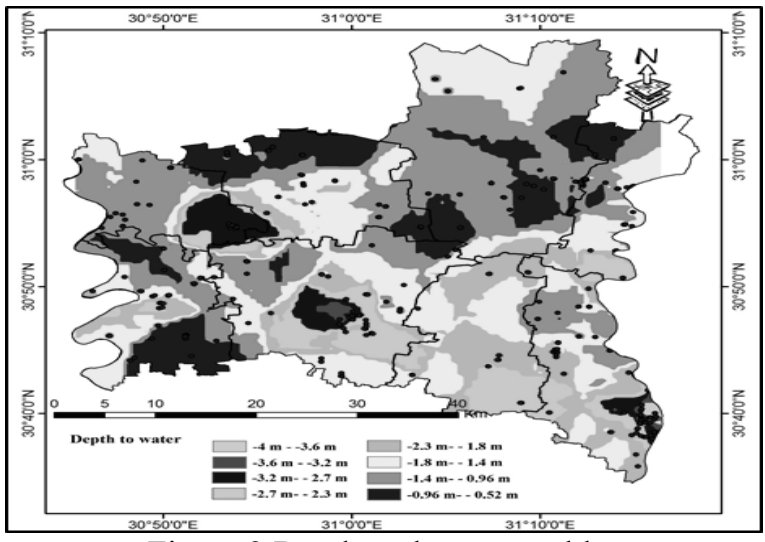

Figure 2 Depth to the water table

Groundwater recharge from rainfall in the Nile Delta occurs only during the winter months. Recharge in the study area carried out through the precipitation and the infiltration from "canals and drains" and the infiltration from the irrigation process. The net recharge from the excess irrigation water ranges from 0.25 to $1.1 \mathrm{~mm} /$ day. The agricultural recharge to the Quaternary aquifer ranges from 0.8 to 1.1 $\mathrm{mm}$ /day for old lands and from 1.9 to $2.1 \mathrm{~mm} /$ day for the reclaimed area (Armanuos et al, 2017). Groundwater recharge from precipitation in the Nile Delta ranges from zero to $20 \mathrm{~mm} /$ year (Armanuos et al. 2017). The recharge of the aquifer occurs through seepage from river branches, irrigation canals and by downward percolation of subsurface drainage water in the traditionally cultivated lowlands.

El-Gharbyia main drain or Kitchener drain (open drain in the protection zone) is one of the largest open drainage systems in the Nile Delta (about $56.5 \mathrm{~km}$ ) and collects about $12 \%$ of the disposal water including agricultural and industrial effluents. In the central and southern portions of the flood plain, the downward leakage towards the aquifer ranges between 0.25 and $0.8 \mathrm{~mm} /$ day, depending on the soil type and irrigation and drainage practices (Nofal et al 2016). The net recharge raster map of the study area was prepared using the inverse distance weight (IDW) interpolation method of ArcGIS Spatial Analyst (Figures 3, 4, 5, and 6). The rating for net recharge varies from six (for Recharge $>102 \mathrm{~mm} /$ year), to one ( 0 to $<51 \mathrm{~mm} /$ year) (Table 1$)$.

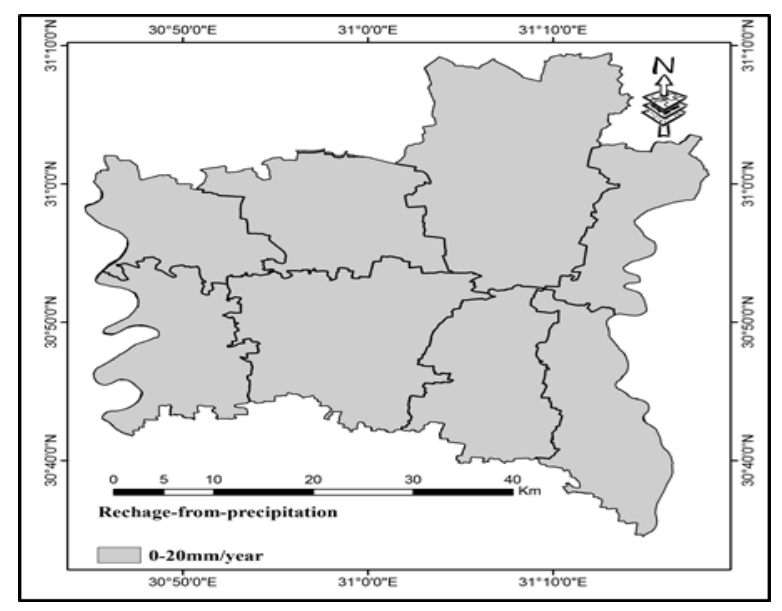

Figure 3 Recharge from precipitation 
Table 1

DRASTIC rating and weighting values (Hamerlick and Ameson.1998).

\begin{tabular}{|c|c|c|c|c|}
\hline DRASTIC Parameters & Range & Rating & $\begin{array}{c}\text { Weight } \\
\text { DRASTIC }\end{array}$ & Total weight (rating $x$ weight) \\
\hline Depth to water table (m) & & & 5 & \\
\hline \multirow[t]{7}{*}{ (D) } & 0 to $<1.5$ & 10 & & 50 \\
\hline & 1.5 to $<4.6$ & 9 & & 45 \\
\hline & 4.6 to $<9.1$ & 7 & & 35 \\
\hline & 9.1 to $<15.2$ & 5 & & 25 \\
\hline & 15.2 to $<22.5$ & 3 & & 15 \\
\hline & 22.5 to $<30$ & 2 & & 10 \\
\hline & $>30$ & 1 & & 5 \\
\hline Recharge (mm/ year) & & & 4 & \\
\hline \multirow[t]{4}{*}{ ( } & 0 to $<51$ & 1 & & 4 \\
\hline & 51 to $<76$ & 2 & & 8 \\
\hline & 76 to $<102$ & 4 & & 16 \\
\hline & $>102$ & 6 & & 24 \\
\hline Aquifer media & & & 3 & \\
\hline \multirow[t]{5}{*}{ (A) } & Fine sand & 4 & & 12 \\
\hline & Medium sand & 6 & & 18 \\
\hline & Coarse sand & 8 & & 24 \\
\hline & Gravel sand & 9 & & 27 \\
\hline & gravel & 10 & & 30 \\
\hline Soil media & & & 2 & \\
\hline \multirow[t]{9}{*}{ (S) } & clay & 1 & & 2 \\
\hline & Silty clay & 2 & & 4 \\
\hline & Silty soil & 3 & & 6 \\
\hline & Silty Sand & 4 & & 8 \\
\hline & Find sand & 5 & & 10 \\
\hline & Medium sand & 6 & & 12 \\
\hline & Coarse sand & 7 & & 14 \\
\hline & Gravel sand & 8 & & 16 \\
\hline & gravel & 9 & & 18 \\
\hline Topography (slope \%) & & & 1 & \\
\hline \multirow[t]{4}{*}{$(\mathrm{T})$} & 12 to $<14$ & 4 & & 4 \\
\hline & 10 to $<12$ & 5 & & 5 \\
\hline & 8 to $<10$ & 6 & & 6 \\
\hline & 0 to $<2$ & 10 & & 10 \\
\hline Impact of the vadoze zone & & & 5 & \\
\hline \multirow[t]{4}{*}{ (I) } & $\begin{array}{c}\text { Very low permeable soil GW } \\
\text { depth }>30 \mathrm{~m}\end{array}$ & 1 & & 5 \\
\hline & $\begin{array}{c}\text { Very low permeable soil GW } \\
\text { depth }>10 \mathrm{~m}\end{array}$ & 2 & & 10 \\
\hline & Medium to low permeable soil & 3 & & 15 \\
\hline & $\begin{array}{l}\text { Very high to high permeable soil } \\
\qquad \mathrm{GW}<10 \mathrm{~m}\end{array}$ & 5 & & 25 \\
\hline Conductivity(m²/day) & & & 3 & \\
\hline \multirow[t]{5}{*}{ (C) } & $<10$ & 1 & & 3 \\
\hline & 10 to $<100$ & 4 & & 12 \\
\hline & 100 to $<300$ & 6 & & 18 \\
\hline & 300 to $<450$ & 8 & & 24 \\
\hline & $>450$ & 10 & & 30 \\
\hline
\end{tabular}




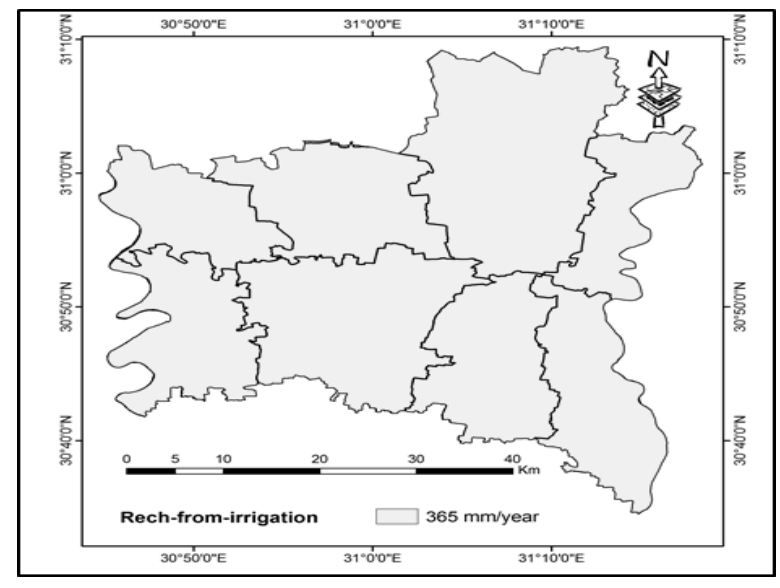

Figure 4 Recharge from Irrigation

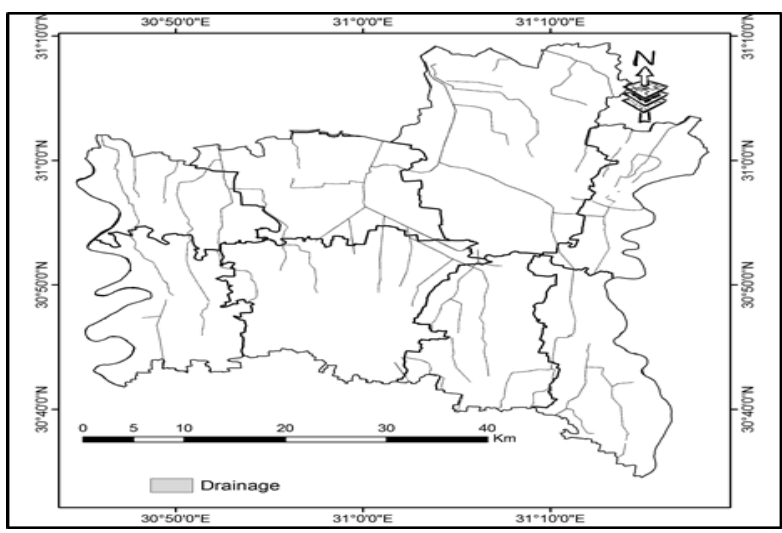

Figure 5 Drains networks

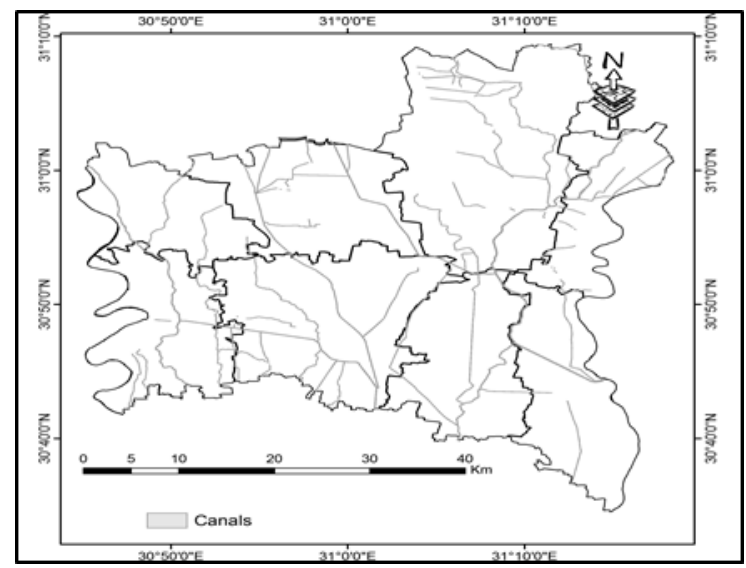

Figure 6 Canals network

Aquifer media (A)

The aquifer performs a major function over the pathway and leaching of contaminant. It is referred to the consolidated and unconsolidated rock, which considered as water storage. Naturally, larger particle size distribution or permeable rocks within the aquifer are giving the higher permeability, and the lower is giving the lower permeability. In this study area, Mit-Ghamr formation represents the aquifer media of the Nile delta aquifer which have fine sand, medium to coarse sand and coarse sand to gravel. The aquifer map of the basin obtained using twenty well logs. (Abd-ELbary 2011). The Aquifer media (A) raster map of the study area was prepared using the inverse distance weight (IDW) interpolation method of ArcGIS Spatial Analysis (Figure 7). The rating for aquifer media varies from 10 (for gravel) to four (for sand) (Table 1).

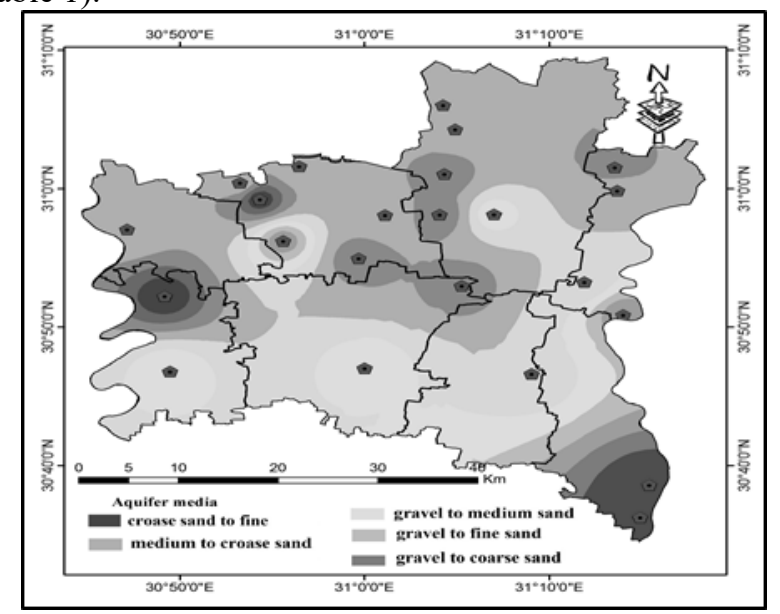

Figure 7 Aquifer media

\section{Soil media (S)}

The soil has a high impact on the amount of recharge that can infiltrate into the ground, and on the ability of a contaminant to move vertically into the vadose zone (Lee 2003). In this study, the soil media data from 34 technical data reports on soil research from Education Buildings Authority digitized for use in ArcGIS technique. The Soil media (S) raster map of the study area was prepared using the inverse distance weight (IDW) interpolation method of ArcGIS Spatial Analysis (Figure 8). The rating for soil media varies from 9 (for gravel) to 1 (for clay) (Table 1).

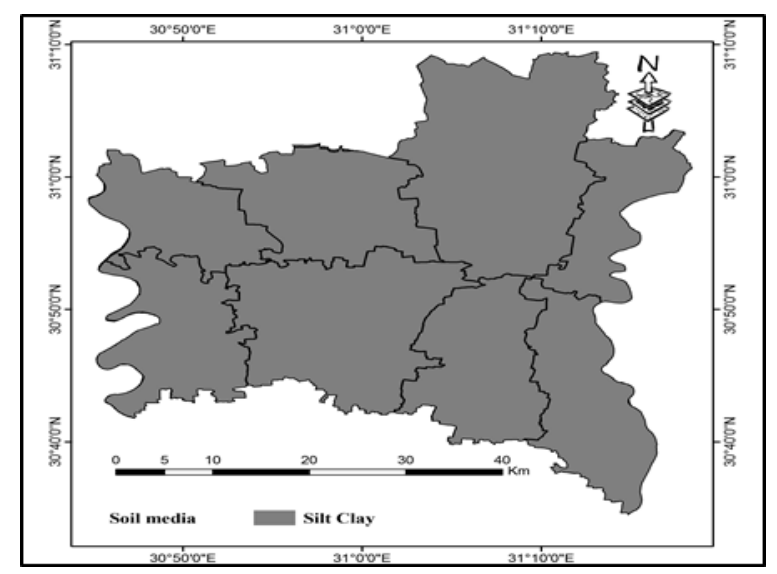

Figure 8 Soil media

\section{Topography (T)}

Topography refers to the slope of an area. Slope affects the flow rate of water at the land surface. Hence, infiltration and contaminant migration increase in the areas of the lower slope. The study area is generally flat and has a very narrow range of slope; in this case, the parameter of topography has one value all over the study area (Abd-ELbary 2011). For evaluation of the topography of the study area (T), topographical maps were digitized (contour interval of $10 \mathrm{~m}$ ). A digital elevation model (DEM) was prepared with a triangular irregular network (TIN) using digitized maps and 
ArcGIS analyst. The slope map of the study area derived from DEM and shown in Figure (9). The rating for slope varies from 10 to four (Table 1).

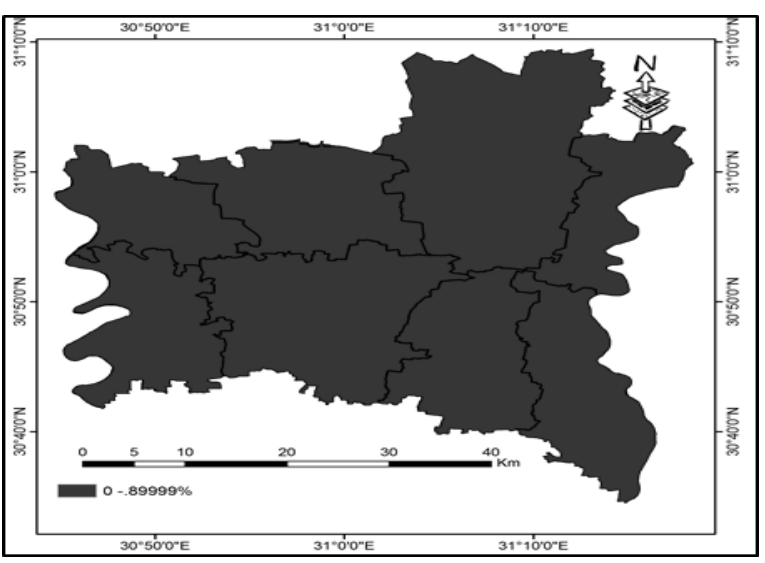

Figure 9 Topography (Slope)

The impact of the vadose zone (I)

The vadose zone is an unsaturated layer above the water table. The impact of the vadose zone on groundwater potential contamination is in principle identical to that of characteristic soil cover. The impact of the vadose zone is a difficult phenomenon, depending on aquifer layers and topographic characteristics (Machdar et al. 2018). A higher impact of the vadose zone if it is composed of porous soils. The impact of the vadose zone rating was evaluated using "557" well logs in the study area from previous investigations (Masoud et al. 2017), showing that it is formed of clay and sand. When the study area has a medium-low thickness of clay cap, it has medium to high permeable soil. The Impact of the vadose zone raster map of the study area prepared using the inverse distance weight (IDW) interpolation method of ArcGIS Spatial Analyst is shown in Figure (10), the rating for soil media varies from five $(\mathrm{GW}<10)$ to 1 $(\mathrm{GW}>30)$, (Table 1).

\section{Hydraulic Conductivity (C)}

Hydraulic conductivity controls the rate of groundwater movement in the saturated zone. Thus, contaminant migration depending on hydraulic conductivity. From the previous study derived from pumping test data to 38 wells to the delta region, hydraulic conductivity varies between 60 $\mathrm{m}^{2} /$ day to $150 \mathrm{~m}^{2} /$ day in the delta.

Hydraulic conductivity raster map of the study area was prepared using the inverse distance weight (IDW) interpolation method of ArcGIS Spatial Analyst. Hydraulic conductivity decreases towards the northern part of the study area (Figure 11). The rating for soil media varies from five $(\mathrm{GW}<10)$ to one $(\mathrm{GW}>30)$ (Table 1$)$.

\section{The final vulnerability map (DVI)}

The final vulnerability map was prepared using the seven hydrogeological data layers in the GIS environment. Taking into consideration the determined ratings and weights, the range of the DRASTIC Vulnerability Index is between 132 and 158, Figure (12). According to data obtained from hydrogeological investigations and field observations, vulnerability of the study area was reclassified into four classes, low (132146) "24\%", medium (146-159) "30\%", high (159-172) "35\%", and very high "11\%.

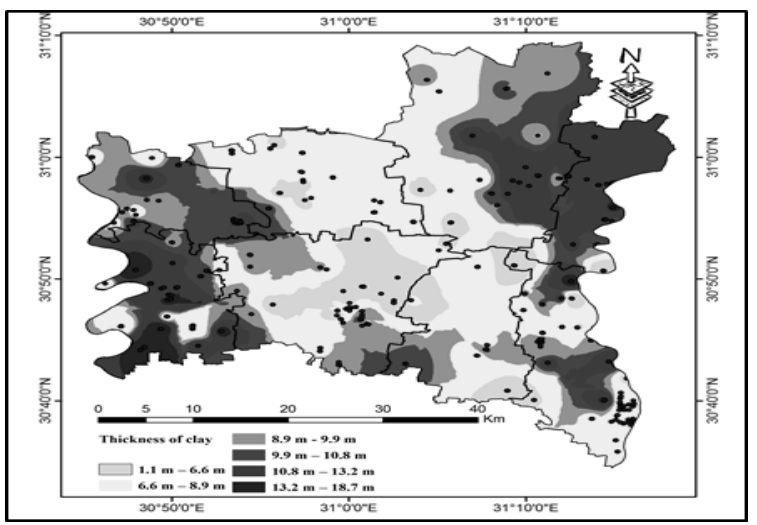

Figure 10 Impact of vadose zone

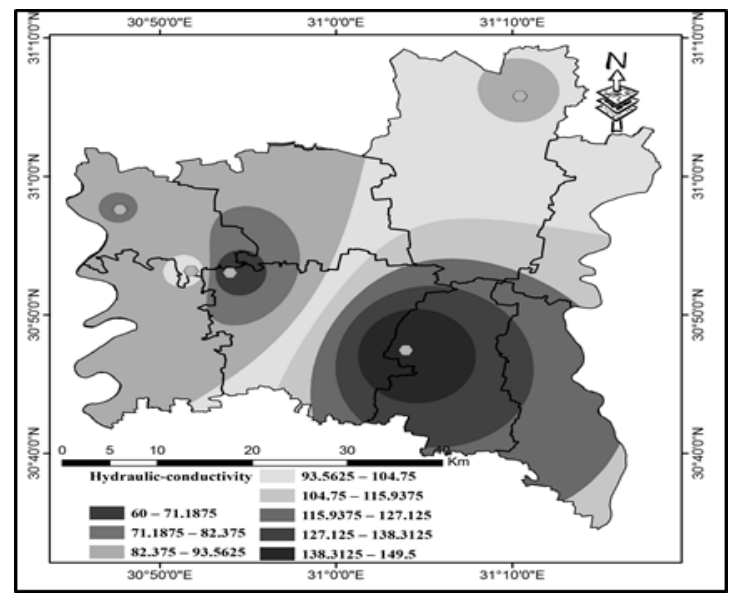

Figure 11 Hydraulic conductivity

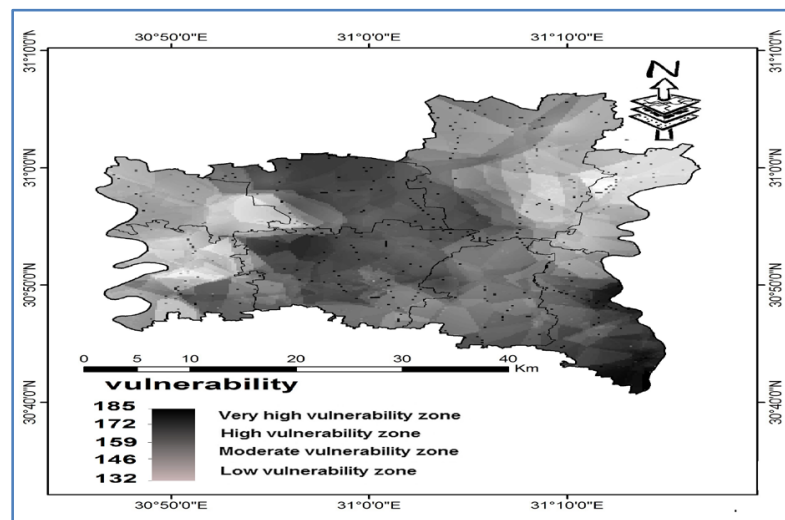

Figure 12 Aquifer Vulnerability map based on the DRASTIC model

\section{DRASTIC index validation}

The nitrates "NO3" concentration in groundwater in the study area is between 0.50 to $30 \mathrm{mg} \backslash \mathrm{l}$ (Abd-Elbary 2011). The maximum acceptable nitrate concentration for human health is $50 \mathrm{mg} / \mathrm{l}$ according to the World Health Organization (WHO 1998) and $45 \mathrm{mg} / \mathrm{l}$ according to (Egyptian health guideline 2007). The spatial distribution of nitrate concentration in the groundwater created using the IDW interpolation methods of ArcGIS Spatial Analyst is shown in (Fig. 13). Nitrate concentration was measured in 76 wells 
during previous investigation (Abd-Elbary, 2011). Based on these analyses, it is concluded that the areas have high nitrate concentration correlated with DRASTIC output.

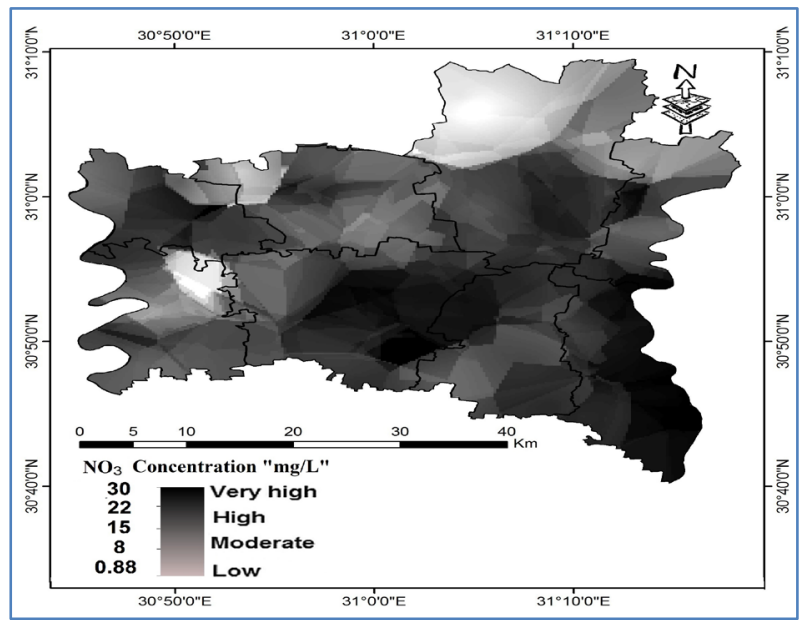

Figure 13 Spatial distribution of nitrate concentration in groundwater

Nitrate concentration measured in 76 wells during the previous investigation (Abd-Elbary 2011). Based on these analyses, it concluded that the areas have high nitrate concentration correlated with DRASTIC output.

\section{CONCLUSIONS}

This study was performed using a GIS model and the DRASTIC method to determine the vulnerability of groundwater in Gharbiya Governorate is the central part of the Nile delta between the two main branches of the Nile Rosetta to the west and Damietta to the west. Sevenparameter maps were prepared in a GIS environment and vulnerability classification of the study area was performed using GIS techniques. The DRASTIC Vulnerability Index was computed between 132 and 185 . Based on hydrogeological field investigations and using a quantile classification method, these values were reclassified into four classes, low (132-146), medium (146-159), high (159-172), and v. high (172-185). These vulnerable aquifer areas cover $24 \%, 30 \%, 35 \%$, and $11 \%$ of the study area, respectively. The vulnerability map obtained from the DRASTIC method gives locations, which must have high priority in terms of protection and pollution prevention. DRASTIC method results are useful in the design of aquifer protection and management strategies. This scenario provides an important benefit in relation to time and economy for local authorities involved in managing groundwater resources. The nitrate concentration of groundwater was evaluated for validation of the DRASTIC results. These evaluations show that high nitrate concentrations correspond to possible nitrate enrichment in the highly vulnerable aquifer medium. This indicates that the obtained results are realistic and representative of the actual situation in the field. Therefore, the DRASTIC method is utilizable in the study area.

\section{REFERENCES}

[1] Aamir Shakoor, Zahid Mahmood Khan, H. Umar Farid, Muhammad Sultan, Aftab Ahmad Khan, Ijaz Ahmad and Muhammad Azmat, (2018). Groundwater Vulnerability Mapping In Faisalabad District Using Gis Based DRASTIC Model. MATEC Web of Conferences 246, 01001 (2018). https://doi.org/10.1051/matecconf/201824601001.
[2] Abd-EL-Bary, M. (2012), Integration of hydrogeological, hydrochemical and geophysical investigations to assess groundwater contamination in central Nile Delta, Egypt. Ph.D. thesis, Geology.

[3] Abd-Elhamid HF, Javadi A, Abdelaty I, sheriff M (2016) Simulation of seawater intrusion in the Nile Delta aquifer under the conditions of climate change. Hydrol Res 47(6):1198-1210. doi:10.2166/nh.2016.157.

[4] Alaa A. Masoud, Mohamed M. El Bouraie, Wafaa El-Nashar1 and Hamdy Mashaly, (2017), Spatiotemporal evaluation of the groundwater quality in Gharbiya Governorate, Egypt, Environ Sci Pollut Res (2017) 24:8256-8278DOI 10.1007/s11356-017-8445-3.

[5] Al-Adamat RAN, Foster IDL, Baban SMJ (2003) Groundwater vulnerability and risk mapping for the Basaltic aquifer of the Azraq basin of Jordan using GIS, remote sensing and DRASTIC. Appl Geogr 23:303-324.

[6] Aller L, Bennett T, Lehr J, Petty R, Hackett G (1987) DRASTIC: a standardized system for evaluating groundwater pollution potential using hydrogeologic settings. USEPA report 600/287/035, Robert S. Kerr Environmental Research Laboratory, Ada, Oklahoma.

[7] Al-Zabet T., (2002), Evaluation of aquifer vulnerability to contamination potential using the DRASTIC method, Environmental Geology, 43, 203-208.

[8] Asaad M. Armanuos, Mona G. Ibrahim, Wael Elham Mahmod, Abdelazim Negm, C. Yoshimura, Jiro Takemura and Bakenaz A. Zidan, (2017), Evaluation of the potential impact of Grand Ethiopian Renaissance Dam and pumping scenarios on groundwater level in the Nile Delta aquifer, Water Science and Technology: Water Supply | $17.5 \mid$.

[9] Attia SM (1975) Pedology and soil genesis of the Quaternary deposits in the region west of the Nile Delta (north and east Wadi ElNatrun). Ph. D. thesis, Fac. of Sci., Ain Shams Univ., 213 p.

[10] Attwa M, Basokur A, Akca I (2014) Hydraulic conductivity estimation using direct current (DC) sounding data: a case study in East Nile Delta, Egypt. Hydrogeol J 22:1163-1178. doi:10. 1007/s10040-0141107-3

[11] Baalousha H (2006) Vulnerability assessment for the Gaza Strip, Palestine using DRASTIC. Environ Geol 50:405-414.

[12] Bahr C (1992) Ein geologists Strukturmodell des Nildeltas as Basis der Klalibrierung eines Grundwasser-stromungsmodlells. Zeitschrift der Deutschen Geologischen Gesellschaft. vol 143, pp 303-315.

[13] Balal Oroji and Zainab Fallah Karimi, 2018 Application of DRASTIC model and GIS for evaluation of aquifer vulnerability: a case study of Asadabad, Hamadan (western Iran). Geosciences Journal Vol. 22, No. 5, p. 843-855, October 2018. https://doi.org/10.1007/s12303-017-00829 ISSN 1226-4806 eISSN 1598-7477.

[14] Cameron E, Peloso GF (2001) An application of fuzzy logic to the assessment of aquifers' pollution potential. Environ Geol 40:13051315.

[15] Dahab KA (1993) Hydrogeological evolution of the Nile Delta after the high dam construction. Ph.D. dissertation, Geology Department, Faculty of Science, Menofia University, Shibin El Kom, Egypt.

[16] El-Fawal FM (1979) Neogene-a quaternary succession of the northern part of the Nile Delta area. M.Sc. thesis, Fac. of Sci., Mansoura Univ.

[17] El-Fayoumi IF, Hegab O A, El Nahas HA(1991) Holocene dietary pattern and evolution of the northern coastal plain of the Nile Delta, Egypt. Mansoura Sci Bull Special Issue 133-149.

[18] Ebraheem AM, Senosy MM, Dahab KA (1997) Geoelectrical and hydrogeochemical studies for delineating ground-water contamination due to salt-water intrusion in the northern part of the Nile Dela, Egypt. Ground Water 35:216-222.

[19] El Alfy M (2012) Integrated geostatistics and GIS techniques for assessing groundwater contamination in Al-Arish area, Sinai,Egypt. Arab J Geosci 5(2):197-215

[20] Gheith AM (1976) Geological studies on the subsurface sediments of Kafr El sheikh well no. 1. Nile Delta. M.Sc. thesis, Fac. of Sci., Mansoura Univ. $156 \mathrm{p}$

[21] Gemail Kh, El-Shishtawy A, El-Alfy M, Ghoneim M, Abd El-Bary M (2011) Assessment of the aquifer vulnerability using geoelectrical and geochemistry measurements. Study case of El Gharbyia main drain, Egypt. J Appl Geophys 75:140-150.

[22] Hamerlinck JD, Ameson CS (1998) (eds) Wyoming groundwater vulnerability assessment handbook, vol I. University of Wyoming, SDVC report, 98-01-1, pp 31-62. http://www.scirp.org/journal/ijg. https://doi.org/10.1007/s40808-018-0545-7.

[23] I Machdar, T Zulfikar, W Rinaldi, and Y Alfiansyah, (2018), Assessment of groundwater vulnerability using DRASTIC Model and 
GIS: A case study of two sub-districts in BandaAceh city, Indonesia, IOP Conf. Series: Materials Science and Engineering 334 (2018) 012032 doi:10.1088/1757-899X/334/1/012032.

[24] Jamrah A, Futaisi AA, Rajmohan N, Al-Yaroubi S (2007) Assessment of groundwater vulnerability in the coastal region of Oman using DRASTIC index method in a GIS environment. Environ Monit Assess. doi: 10.1007/s10661-007-0104-6.

[25] Kashef A (1983) Salt water intrusion in the Nile Delta. Groundwater 21(2):160-167

[26] Khaled S. Gemail1, Mohamed El Alfy, Mohamed F. Ghoneim, Ahmed M. Shishtawy, Abd El-Bary M.H. (2017), Comparison of DRASTIC and DC resistivity modeling for assessing aquifer vulnerability in the central Nile Delta, Egypt, Environ Earth Sci (2017) 76:350 DOI $10.1007 / \mathrm{s} 12665-017-6688-4$

[27] Lee S (2003) Evaluation of waste disposal site using the DRASTIC system in southern Korea. Env Geol 44:654-664

[28] Mabrouk B, Arafa S, Gemail Kh (2015) Water management strategy in assessing the water scarcity in Northern Western region of Nile Delta, Egypt Geophysical Research Abstracts, vol. 17, EGU2015-15805, 2015 -EGU General Assembly 2015

[29] Melloul AJ, Collin M (1998) A proposed index for aquifer water quality assessment: the case of Israel's Sharon region. J Environ Manage 54(2):131-142

[30] Mendoza JA, Barmen G (2006) Assessment of groundwater vulnerability in the Rio Artigas basin, Nicaragua. Environ Geol 50:569-580

[31] Merchant JW (1994) GIS-based groundwater pollution hazard assessment: a critical review of the DRASTIC model. Photogramm Eng Remote Sens 60(9):1117-1127

[32] Moulay Lhassan Sadiki1, Lhoussaine El Mezouary, Abdelaziz Khomsi1, Badr Benseddik, El Houssine El Gasmi1, Mohamed El Bouhaddioui, Malika Kili, Jamal Chao, Bouabid El Mansouri, Aicha Benmohammadi, (2018). Groundwater Protection Using DRASTIC Vulnerability Maps and ArcFem Tools for Perimeter Protection: A Case Study in the Charf El Akab Aquifer (Morocco North). International Journal of Geosciences, 2018, 9, 289-307

[33] Nofal E.R., (2016), "Sea Water Intrusion in Nile Delta in Perspective of Climate Changes and Aquifer Heterogeneity", Ph.D. Thesis, Faculty of Engineering, Cairo University.

[34] Pranjay Joshi and Pankaj Kumar Gupta, (2018). Assessing Groundwater Resource Vulnerability by Coupling GIS Based DRASTIC and Solute Transport Model in Ajmer District ,Rajasthan. JOURNAL GEOLOGICAL SOCIETY OF INDIA Vol.92, July 2018, pp.101-106.

[35] Rahim Barzegar, Asghar Asghari Moghaddam, Ravinesh Deo, ElhamFijani, Evangelos Tziritis, (2018). Mapping groundwater contamination risk of multiple aquifers using a multi-model ensemble of machine learning algorithms Science of the Total Environment 621 (2018) 697-712.

[36] Said R (1981) the geological evolution of the River Nile, I-VII, 1-151. Springer, Heidelberg

[37] Secunda S, Collin M, Melloul AJ (1998) Groundwater vulnerability assessment using a composite model combining DRASTIC with extensive land use in Israel's Sharon region. J Environ Manage 54:39 57

[38] Sener E, Sener S, Davraz A (2009) Assessment of aquifer vulnerability based on GIS and DRASTIC methods: a case study of the SenirkentUluborlu Basin (Isparta, Turkey). Hydrogeol J 17:2023-2035

[34] Sestini G (1989) Nile Delta: a review of depositional environments and geological history. In: Whateley MKG, Pickering KT (eds) Geological Society Special Publication, vol 40, pp 99-127

[39] Sherif M (1999). The Nile Delta aquifer, Ch 17. In: Seawater intrusion in coastal aquifers: concepts, methods, and practices. In: Bear et a (eds) Book series, theory and application of transport in porous media, vol 14. Kluwer Academic Publishers, Netherlands, pp 559-590 Kim and Hamm 1999;

[40] Sherif M, Singh V (2002) Effect of groundwater pumping on seawater intrusion in coastal aquifers. Agr Sci 7(2):61-67

[41] Sherif MM, Sefelnasr A, Javad A (2012) Incorporating the concept of the equivalent freshwater head in successive horizontal simulations of seawater intrusion in the Nile Delta aquifer, Egypt. J Hydrol 464 465:186-198. doi:10.1016/j.jhydrol.2012.07.007

[42] Shobharam Ahirwar, and J. P. Shukla, (2018). Assessment of Groundwater Vulnerability in Upper Betwa River Watershed using GIS-based DRASTIC Model. JOURNAL GEOLOGICAL SOCIETY OF INDIA Vol.91, March 2018, pp.334-340.

[43] Smitarani Lad, Rashmi Ayachit, Ajaykumar Kadam, Bhavana Umrikar,(2018). Groundwater vulnerability assessment using
DRASTIC model: a comparative analysis of conventional, AHP, Fuzzy logic and Frequency ratio method. Modeling Earth Systems and Environment

[44] Thirumalaivasan D, Karmegam M, Venugopal K (2003) AHPDRASTIC: software for specific aquifer vulnerability assessment using DRASTIC model and GIS. Environ Model Softw 18:645-656

[45] Troger U, Holtorff G, Arlt H, Asbrand M, Bahr C, Baumann R, Moser H (1993) Meerwasserintnision im Delta arider und senuaride: Gebieteam Beispiel des Nildeitas: Berlin. Germany. Sondenorschungsbereich69 (SFB69-TUB): Geouisscnschaftlichc Problem in anden und semiariden Gebieten, Berichisband 1990-1993. Tell C \{internal report . pp 1411-1470.

[46] United State Environmental Protection Agency E., (1985), DRASTIC: a standard system for evaluating groundwater potential using hydrogeological settings, Ada, Oklahoma.

[47] Wang Y, Merkel BJ, Li Y, Ye H, Fu S, Ihm D (2007) Vulnerability of groundwater in Quaternary aquifers to organic contaminants: a case study in Wuhan City, China. Env Geol 53:479-484

[48] WHO (1998) Guidelines for drinking water quality. Addendum to vol 2, 2nd edition. Health criteria and other supporting information (WHO/EOS/98.1). World Health Organization, Geneva

[49] Z. Mfonka, J.R. Ndam Ngoupayou, P.-D. Ndjigui, A. Kpoumie, M. Zammouri, A.N. Ngouha, O.F. Mouncherou, F. Rakotondrabe, E.H. Rasolomanana, (2018). A GIS-based DRASTIC and GOD models for assessing alternates aquifer of three experimental watersheds in Foumban (Western-Cameroon).Ground-water for Sustainable Development 7: 250-264.

[50] Zaghloul Z, Taha A, Hegab O, El Fawal F (1977) The NeogeneQuaternary sedimentary basins of the Nile Delta. Egyptian J Geol 21(1):1-1

[51] Zaghloul ZM, Taha HH, Hegab OA, El-Fawal FM (1979) The PlioPleistocene Nile Delta subenvironments, stratigraphic section, and genetic class. Geol. Soc. V. 1x, Cairo 